\title{
Oncologists as Role Models for Anti-tobacco Campaign
}

\author{
Pankaj Kumar Garg
}

Received: 11 February 2014 / Accepted: 11 December 2014 / Published online: 19 December 2014

(C) Indian Association of Surgical Oncology 2014

\section{Dear Sir,}

Delhi witnessed the golden moment of amalgamation of four Indian oncological societies-Indian Association of Surgical Oncology, Indian Society of Medical and Pediatric oncology, Association of Radiation Oncologists of India, and Indian Society of Oncology in the form of Indian Cancer Congress (ICC) 2013. In the academic sanctity of ICC, it was absolutely disheartening to see a few delegates smoking around the venue.

An oncologist is perhaps the best person to understand the menace of tobacco consumption, and rightly so, is the key person to preach the society its deleterious effects. They are expected to be the role models of healthy living for the society in accordance with Hippocratic Oath. Code of medical ethics for the doctors [1], laid down by Medical Council of India, clearly states, "Who- so-ever chooses his profession, assumes the obligation to conduct himself in accordance with its ideals. A physician should be an upright man, instructed in the art of healings. He shall keep himself pure in character and be diligent in caring for the sick; he should be modest, sober, patient, prompt in discharging his duty without anxiety; conducting himself with propriety in his profession and in all the actions of his life." [1] This bestows them with

\section{P. K. Garg $(\bowtie)$}

Department of Surgery, University College of Medical Sciences and

Guru Teg Bahadur Hospital, Dilshad Garden, Delhi 110095, India

e-mail: dr.pankajgarg@gmail.com

\section{P. K. Garg}

Department of Surgical Oncology, All India Institute of Medical Sciences, New Delhi 110029, India the responsibility to profess and live with the health values; they must refrain themselves in indulging health risk behavior. An oncologist who consumes tobacco products himself would prove to be a suicidal slap in the face of any anti-tobacco campaign. How a policeman would look if he is found to be not abiding by the law of the land himself? Pentz et al. [2] states that oncologists are "professionally obligated" to abstain from the tobacco products. Based on a questionnaire based study, Olive et al. [3] concluded that an health professional, who smokes himself, can never prove to be as effective in counseling patients to quit smoking as other health professional who does not smoke. More worrisome is the fact that the health professionals who smoke have the potential to affect unintentionally the smoking behaviors of others through modeling [3].

It cannot be overstressed that oncologists are duty-bound to abstain from consuming tobacco products; they must prove to be a role model for the society in an endeavor for a tobacco free world.

\section{References}

1. Medical Council of India. Professional Conduct, Etiquette and Ethics Regulations, (2002) Accessed from http://www.mciindia.org/rulesand-regulation/Code $\% 20$ of $\% 20$ Medical $\% 20$ Ethics $\% 20$ Regulations. pdf. On 07 Feb 2014

2. Pentz RD, Berg CJ (2010) Smoking and ethics: what are the duties of oncologists? Oncologist 15(9):987-993

3. Olive KE, Ballard JA (1992) Attitudes of patients toward smoking by health professionals. Public Health Rep 107:335-339 